Cahiers $d u$ MONDE RUSSE

\section{Cahiers du monde russe}

Russie - Empire russe - Union soviétique et États indépendants

$53 / 1 \mid 2012$

Pratiques du droit et de la justice en Russie (XVIIIe-XX siècles)

\title{
РОССИЙСКИЙ ПЛЕН 1914-1917 ГГ. КАК ПРОСТРАНСТВО ПОЛИТИКО-ИДЕОЛОГИЧЕСКИХ МАНИПУЛЯЦИЙ
}

\section{ТЕОРИИ ЦЕНТРА И ПРАКТИКИ ПЕРИФЕРИИ}

War captivity in Russia between 1914 and 1917 as a space for political and ideological manipulation. Central theories and peripheral practicesLes théories du centre et les pratiques de la périphérie La captivité de guerre en Russie entre 1914 et 1917, espace de manipulations politiques et idéologiques. Les théories du centre et les pratiques de la périphérie

\section{Наталья В. Суржикова}

\section{(2) OpenEdition}

\section{Journals}

\section{Édition électronique}

URL : http://journals.openedition.org/monderusse/9373

DOI : $10.4000 /$ monderusse. 9373

ISSN : $1777-5388$

Éditeur

Éditions de l'EHESS

\section{Édition imprimée}

Date de publication : 15 mars 2012

Pagination : 247-266

ISBN : 978-2-7132-2390-7

ISSN : $1252-6576$

Référence électronique

Наталья В. Суржикова, « Российский плен 1914-1917 гг. как пространство политикоидеологических манипуляций », Cahiers du monde russe [Онлайн], 53/1 | 2012, Выложить онлайн 02 avril 2015, Наводить справки в 03 mai 2019. URL : http://journals.openedition.org/ monderusse/9373; DOI : 10.4000/monderusse.9373 


\title{
РОССИЙСКИЙ ПЛЕН 1914-1917 ГГ. КАК ПРОСТРАНСТВО ПОЛИТИКО-ИДЕОЛОГИЧЕСКИХ МАНИПУЛЯЦИЙ
}

\author{
Теории центра и практики периферии
}

Политизация плена как тенденция обозначилась буквально с первых дней Первой мировой войны, придав противоборству сражавшихся сторон дополнительную остроту. При этом политико-идеологические манипуляции в пространстве российского плена 1914-1922 гг. были связаны прежде всего с попытками утилизации этноконфессиональных и социальных статусов военнопленных, динамика конструирования и иерархизации которых со всей очевидностью отражала трансформации внешнеполитического и внутриполитического ландшафта. По словам же А. Рачамимова, «этнизация» российского плена и вовсе стала «самой известной главой» его истории ${ }^{1}$. Написанная в духе лучших традиций классицизма, она закономерно предполагала героев исключительно положительных, с одной стороны, и героев исключительно отрицательных - с другой. Однако российский плен предполагал еще и многих других действующих лиц, интересы которых, противореча друг другу, не оставили настоящей исторической драме никаких шансов на соответствие классицистскому канону.

Нейтрализованные воины германской, австро-венгерской, турецкой и болгарской армий с первых же дней плена столкнулись с тем, что политика российских властей по отношению к неприятельским солдатам и офицерам не отличалась однородностью. В России, как выяснилось, куда выгоднее было быть славянином, французом, итальянцем, датчанином, армянином в крайнем случае румыном, нежели немцем, венгром, турком или евреем.

1. A. Rachamimov, POWs and the Great War: Captivity on the Eastern Front, New York, 2002, p. 115 . 
При этом ранжирование пленных по этническому признаку не было чем-то из ряда вон выходящим, соответствуя общей логике осуществлявшейся в стране политики населения ${ }^{2}$. Ее истоки следует искать во второй половине XIX в., когда этническое разнообразие впервые стало восприниматься как важный ресурс имперской власти. Рационализация этого разнообразия зиждилась прежде всего на достижениях такой «науки», как военная статистика. С введением в 1874 г. всеобщей воинской повинности, когда Россия, по мысли Дж. Сэнборна, впервые достигла состояния «массовой политики», то есть, политики с массами и через массы, военные усилили работу с населением, разбив его на категории, каждой из которых отводилось свое место в иерархии, постепенно превращавшейся из этнической в социальную․ Именно после реформы русские военные стратеги, очевидно, вслед за известным современным этнографом А.Ф. Риттихом ${ }^{4}$, сделали разделение населения на безусловно надежные, относительно надежные и неблагонадежные этнические группы стереотипным. Созданная таким образом концепция национальностей, в рамках которой оценки «качества» населения строились на псевдонаучных этнических стереотипах, открывала широкие возможности для тех или иных манипуляций. С началом же Первой мировой войны «мобилизация этничности» ${ }^{5}$ стала одним из главных средств социальной мобилизации, прискорбно сопровождаясь целым набором карательных акций в отношении «подозрительных» народностей ${ }^{6}$.

Коснувшись практически всего населения, этнодифференцирующая политика просто не могла не коснуться военнопленных противника, выстраивая барьеры между которыми власти надеялись, как минимум, повысить их

2. П. Холквист, «Вычислить, изъять и истребить: Статистика и политика населения в последние годы царской империи и в Советской России», in Р. Суни,Т. Мартин., ред., Государство наций: Империя и национальное строительство в эпоху Ленина и Сталина, M., 2011, c. 141, 143.

3. J. Sanborn, Drafting the Russian Nation: Military Conscription, Total War, and Mass Politics, 1905-1925, DeKalb, 2003, p. 100-112. См. также: Лапин В., «Армии империи - империя в армии: организация и комплектование вооруженных сил России в XVI начале XX вв.», Ab Imperio, 2001, № 4, с. 109-127; Й. Петровский-Штерн, Евреи в русской армии 1827-1914 г2., M., 2003; D. Beyrau, «Old Prejudices and New Opportunities: Jews in the Russian Armed Forces, 1900 to 1926», Osteuropa, 53, 2003, p. 1793-1809; G. Vitarbo, «Nationality Policy and the Russian Imperial Officer Corps, 1905-1914», Slavic Review, 66, 4 (Winter, 2007), p. 682-701; и др.

4. Ж. Кадио, Лаборатория империи: Россия/СССР, 1860-1940, М., 2010, с. 33-35.

5. М. Термин фон Хагена. См.: M.Von Hagen «The Great War and the Mobilization of Ethnicity in the Russian Empire: Conflict and State-Building», Post-Soviet Political Order, London, 1998, p. 34-57.

6. См. об этом: Э. Лор, Русский национализм и Российская империя: Кампания против «вражеских подданных» в годы Первой мировой войны, М., 2012; С.Г. Нелипович, «Репрессии против подданных ‘Центральных держав’: Депортации в России, 1914-1918», Военно-исторический журнал, 1996, № 6, с. 32-42; E. Lohr, «The Russian Army and the Jews: Mass Deportation, Hostages, and Violence during World War I», Russian Review, 60 (3), Jul., 2001, p. 404-419; J. Sanborn, «Unsettling the Empire: Violent Migrations and Social Disaster in Russia during World War I», The Journal of Modern History, 77 (2), June, 2005, p. 290-324; и др. 
управляемость. Главным «успехом» этой политики принято считать формирование в структурах Русской императорской армии национальных частей, резервом для которых служили вражеские военнослужащие так называемых «дружественных» народностей. Действительно, уже в августе 1914 г. Генеральный штаб серьезно обсуждал вопрос о формировании чешских, словацких и польских частей, а также одобрил создание армянских, финских и латышских войск ${ }^{7}$. Спустя месяц в России началось формирование чешских, в октябре - польских, в 1915 г. - сербских и в 1916 г. - румынских боевых подразделений. К концу 1917 г. инородческие части русской армии, среди которых наиболее многочисленной стал организованный в Киеве Чешский легион, насчитывали десятки тысяч человек. Останавливаться на истории этих формирований, многократно написанной (и переписанной) нет смысла, поскольку фактическая сторона этой истории известна и подлежит ревизии исключительно с интерпретационной точки зрения.

Среди обстоятельств создания национальных подразделений русской армии следует, однако, пренепременно остановиться на следующем. В приказе военного министра «О формировании особых чешских воинских частей из добровольцев» от 8 августа 1914 г. - как и в его последующих аналогах - явно просвечивали признаки того, что серьезной ставки на эти соединения власти России не делали. Сформировать планировалось только

[...] один или два полка, или в зависимости от числа добровольцев батальон хотя бы из двух рот. Употребление не боевое, а из-за политических соображений, и с ориентацией на будущее восстание [в Чехии], постоянной и прочной организации не придавать, ибо в дальнейшем будут действовать отдельными партиями (по принципу добровольцев-китайцев под командованием полковника [А.С.] Мадритова в 1905 г.). Формировать без пулеметных команд и связи $[\ldots]^{8}$

Многие эксперты вообще полагают, что в течение первых трех лет войны формирования, рекрутировавшиеся из военнопленных, серьезной силы не представляли как по причине своей малочисленности, так и по причине их общего деморализованного состояния 9

«Тех пленных, которые на театре войны были зачислены в ряды чешской дружины и затем эвакуированы за ранами в глубь империи, пленными не

7. М. Фон Хаген, «Пределы реформы: национализм и русская императорская армия в 1874-1917 годы», Отечественная история, 2004, № 5, с. 44.

8. Б. Татаров, Б. Пануш, «Чехословацкие части в России, 1914-1917 гг.», Цейхгауз, 2001, № 4 , c. 28 .

9. Rachamimov, POWs and the Great War, p. 115-118, См. также: P. Gatrell, «Prisoners of War on the Eastern Front during World War I», Kritika: Explorations in Russian and Eurasian History, 6 (3), Summer, 2005, p. 557-566; H. Leidinger, V. Moritz, Gefangenschaft, Revolution, Heimkehr: Die Bedeutung der Kreigsgefangenenproblematik für die Geschichte des Kommunismus in Mittel- und Osteuropa 1917-1920, Wien, 2003, s. 217-228; R. Nachtigal, Russland und seine österreichisch-ungarischen Kriegsgefangenen 1914 bis 1918, Remshalden, 2003, s. 26, 51. 
считать», - повелел Верховный Главнокомандующий в августе 1915 г. $^{10}$ Однако эта мера была лишь одной из немногих великих милостей, демонстрировавших глубокую благосклонность властей России к пленникам «дружественных» народностей. Показательно, что в даровавшем ее документе далее отмечалось:

Впредь попавшие к нам в плен чехи и словаки не могут приниматься сразу на театре войны в [Чешскую] дружину, а сначала должны направляться во внутренний район и только оттуда могут посылаться в названную дружину те из них, за коих ручаются представители чешских организаций ${ }^{11}$.

Источники свидетельствуют, что царское правительство явно осторожничало не только с призывом этнически «надежных» пленников в войска. Пристальное изучение казуистики обнаруживает, что, как и политика национальностей в более широкой перспективе, политика национальностей в пространстве плена была, по существу дела, бессистемной и неупорядоченной. Больше того, есть основания думать, что курс на стремительную этнизацию плена был взят российскими властями только после толчка «извне». 13 августа 1914 г. Главное управление Генерального штаба извещало Министерство внутренних дел:

Министерство иностранных дел, в секретном сношении от 7 сего августа за № 247, уведомило о полученном со стороны нашего императорского посла в Париже [А.П. Извольского] сообщения о том, что по имеющимся во Франции сведениям, Германия избегает направлять нижних чинов эльзаслотарингцев против Франции, а поляков против России, в виду чего, в действующих против Франции германских войсках, естественно, следует ожидать значительного количества поляков. Учитывая эту возможность, французское правительство имеет опубликовать распоряжение о выделении из общего состава всех пленных и раненых нижних чинов польской национальности, по каковому поводу гофмейстером Извольским высказано, что признавалось бы весьма желательным сделать то же самое и у нас в России относительно эльзас-лотарингцев $[\ldots]^{12}$

Зароненные таким образом зерна неравноценного отношения к пленным иностранцам в зависимости от их этнической принадлежности дали всходы, но только совсем не на той ниве, где ожидалось. Прежде всего они проросли посредством активизации деятельности в России всевозможных славянских организаций, и, в частности, чешских обществ, представители которых И. Орсаг, И. Клецанда, О. Червеный и С. Коничек 17 сентября 1914 г. вручили

10. Государственный архив Пермского края (ГАПК), ф. 146, оп. 1, д. 94, л. 204.

11. Там же.

12. Государственный архив Российской Федерации (ГАРФ), ф. 102, 2-е делопроизводство, оп. 71 , д. 84 , л. 20. 
Николаю II некий меморандум по чехословацкому вопросу. Однако предложенными в нем услугами имперская администрация, вопреки «рефлекторно» актуализировавшейся с началом войны панславистской демагогии ${ }^{13}$, пользоваться не спешила. Изданное 7 октября 1914 г. «Положение о военнопленных» не содержало даже намека на какой-то особенный подход к братьям-славянам или иным «дружественным» пленным ${ }^{14}$. Его идея долго витала в воздухе и, возможно, витала бы и дальше, если бы не разосланная осенью 1915 г. по всем военным округам России записка «По делу военнопленных славян», авторизованная именем «славянского деятеля» Алексея Геровского, связанного, очевидно, с созданным 30 октября 1914 г. Всероссийским попечительством о пленных славянах. В настоящей записке выражались серьезные опасения в том, что при существовавших условиях содержания военнопленные славяне, «сдавшиеся по большей части в плен из любви к России, сознательно возвратятся на родину русофобами» ${ }^{15}$, и тем самым недвусмысленно указывалось на весьма незначительные доселе усилия официальных властей по поддержке пленных славян. Настаивая на ней, А. Геровский указывал, что без лишней траты времени и денег дело можно организовать так, чтобы

сохранить не только существующие уже симпатии военнопленных славян к России, но и развить их среди сотен тысяч южных и западных славян, которые по тем или другим причинам относились до сих пор равнодушно или недружелюбно к России. ${ }^{16}$

При этом с точки зрения технической, по мнению автора, не нужно было изобретать ничего особенного, взяв на вооружение уже апробированный в Германии механизм «индоктринации» пленных. А именно: не отвлекая никого от насущных забот военного времени, необходимо сосредоточить славян в специальных местах водворения и «систематически возбуждать» в них ненависть к «врагам славянства», так же как немцы в специальных лагерях для малороссов или татар методично прививали последним ненависть к русским ${ }^{17}$.

Пламенный призыв «воспитать в желательном для России духе сотни тысяч людей» сподвиг российские власти к намеченному еще в 1914 г. $^{18}$, но так и не

13. См., напр.: «Воззвание к славянам», Новое время, 1914, 1 авг; «Примирение братских народов», Там же, 2 авг.

14. Собрание узаконений и распоряжений правительства, 1914, 16 окт. № 281.

15. ГАРФ, ф. 102, 2-е делопроизводство, оп. 73, д. 334, л. 12-13 об.

16. Там же.

17. См. об этом: Andrew D. Evans, Anthropology at War: World War I and the Science of Race in Germany, Chicago, 2010; A. Roshwald, Ethnic Nationalism and the Fall of Empires: Central Europe, Russia and the Middle East, 1914-1923. London, 2001; и др.

18. См. об этом: Российский государственный военно-исторический архив (РГВИА), ф. 1759 , оп. 3, д. 433 , л. 183. 
начатому до появления ретроспективного документа «ограждению» военнопленных славян «от враждебного и крайне оскорбительного отношения к ним немцев и венгров ${ }^{19}$. В то время как пленные славяне подлежали размещению в Московском, Казанском, Омском и Туркестанском военных округах, национальные «аутсайдеры» - немцы, венгры, евреи и турки, включая увечных, - высылались в «дальние округа Сибири» - Иркутский и Приамурский. Еще в середине 1915 г., после вступления Италии в войну на стороне Антанты, в Симбирске, Сызрани и Царицыне решено было сосредоточить «дружественных» пленных из числа этнических итальянцев, уроженцев Тренто, Триеста и других городов Габсбургской монархии с итальянским населением. В сентябре на места пришла новая телеграмма, предписывавшая «свозить» их в город Кирсанов под Тамбовом. В той же телеграмме указывалось на необходимость отправки в подмосковную Каширу пленных эльзасцев и лотарингцев, с высылкой которых власти попросили в очередной раз поторопиться в начале января 1916 г. Немногочисленные датчане из германского Шлезвига подлежали перемещению в подмосковный же Павлов Посад с предоставлением им «по возможности более мягкого режима содержания» в знак признательности российского правительства властям Дании за поддержку бежавших из германского плена чинам русской армии ${ }^{20}$.

Проблема, правда, состояла в том, что эти решения в отношении пленных славян и прочих «ирредентистов» были приняты, когда значительная часть вражеских военнослужащих на правах «аренды» принадлежала гражданским властям и использовалась на общественных работах, казенных и частных предприятиях, а также в сельском хозяйстве. В этой связи соответствующий циркуляр за № 34150 от 23 октября 1915 г. уже по прошествии пары месяцев обнаружил свою декларативность. 25 декабря 1915 г. помощник военного министра по Главному управлению Генерального штаба информировал товарища министра внутренних дел:

[...] Проведение ... разделения славян на группы по всей, предложенной г. Геровским, полноте не представляется осуществимым в виду следующих обстоятельств. Распределение пленных славян на отдельные мелкие группы было бы связано с необходимостью крайне сложного перемещения огромного числа таковых пленных из одних пунктов водворения в другие, что, без сомнения, создало бы весьма большие затруднения для провозоспособности наших железных дорог, и без того уже чрезмерно занятых перевозками войсковых частей и военных грузов. Независимо от сего, намеченному полному распределению препятствует также и привлечение пленных славян на разного рода работы, имеющие важное государственное значение, ... причем в ближайшем времени, с наступлением весны, имеется в виду особенно широко использовать, по возможности, всех славян для полевых работ $[\ldots]^{21}$.

19. ГАПК, ф. 146, оп. 1, д. 94, л. 71.

20. Там же, л. 29, 30, 55, 68, 71-71 об., 93, 99, 99 об.

21. ГАРФ, ф. 102, 2-е делопроизводство, оп. 73, д. 334, л. 26. 
В условиях, когда труд пленных во всю входил в обиход, региональные экономические элиты и вовсе саботировали полученные свыше предписания, на что недвусмысленно указывал пример Уральского региона. В то время как центральные власти настойчиво рекомендовали привлекать к наиболее ответственным работам, - то есть работам на оборону, - исключительно пленных славян, многие хозяйственники открыто заявили о том, что национальность пленных им безразлична.

[...] Честь имеем просить военно-промышленный комитет исходатайствовать разрешение на отпуск пленных в наше предприятие 150 человек, указывая, что мы имеем казенный заказ на нужды войны и сильно нуждаемся в рабочих. [...] Из вышеуказанного количества желаем иметь 100 человек чернорабочих и 50 человек плотников, слесарей и электротехников, притом национальность их роли не играет, -

писал управляющий Вознесенскими асбестовыми рудниками В.И. Жирарда в Уральский областной военно-промышленный комитет 28 сентября 1915 г. Обращаясь по тому же адресу в октябре 1915 г., Т.Д. Тепляков, владелец чугунолитейного и механического завода в Каслях, указывал:

[...] Для моего завода потребно военнопленных без различия национальности следующих специальностей: токарей - 5 человек, слесарей -5 человек, инструментальщиков - 1 человек, формовщиков 10 человек, литейщиков - 1 человек, чернорабочих -4 человек, всего 26 человек. ${ }^{22}$

Не проявили должного уважения уральские промышленники и к наложенному властями «вето» на использование «враждебных» немцев в заводских цехах. Алапаевский, Баранчинский, Верхне- и Нижне-Салдинский, Сосьвинский и целый ряд других заводов просто проигнорировали указанный запрет. «...Допущение военнопленных к заводским работам является единственным средством, хотя бы отчасти восполняющим отсутствие рабочих»,--настаивала администрация Нижне-Тагильского и Луньевского горных округов наследников П.П. Демидова, князя Сан-Донато ${ }^{23}$. Дискуссия затянулась до середины 1916 г. и закончилась тем, что с нормой закона местные хозяйственники так и не согласились, выторговав право на допуск немцев к заводским работам при условии назначения их в дневные смены и при усиленной охране. Некоторые же предприятия, в частности, в Богословский и Гороблагодатский горные округа, вообще не пошли ни на какой компромисс, отделавшись заявлением о том, что «охрана дорога, а ночные смены неизбежны» ${ }^{24}$.

22. Государственный архив Свердловской области (ГАСО), ф. 123, оп. 1, д. 9, л. 56, 115.

23. ГАСО, ф. 183, оп. 1, д. 71, л. 207.

24. Там же, л. 330-333. 
Пожаловался пермский губернатор на «ослушников» или нет, но весьма показательно, что предприятия региона «удостоились» даже специального внушения со стороны Министерства торговли и промышленности:

По имеющимся данным, на некоторых горных и металлургических предприятиях Урала, обслуживаемых смешанным контингентом пленных, славяне, будучи размещены необособленным порядком от мадьяр и немцев, претерпевают всякие обиды и притеснения со стороны этих последних на почве племенной вражды вообще и недовольства дружественным отношением славян к России. В видах устранения на будущее время повторения такого недопустимого явления военное министерство признало необходимым, чтобы пленные рабочие из славян размещались на горных и горнозаводских предприятиях безусловно обособленно от враждующих с ними мадьяр и немцев, причем желательно, в мере возможности, соблюдать отграничение означенных отдельных элементов пленных и при распределении их по работам. ${ }^{25}$

К столь радикальной «этнизации» плена на местах оказались не готовы, встретив ее в штыки. Так, главноначальствующий Уфимской губернии и начальник Златоустовских горных заводов, принадлежавших казне, сразу обратились в Главное управление Генерального штаба с ходатайством об отмене распоряжения об обособленном размещении на работах пленных славян от мадьяр и немцев ${ }^{26}$. Специфика организации горного и металлургического производств, а также нехватка помещений превращали расселение пленных по национальному принципу в роскошь, которую на местах считали излишней ${ }^{27}$. Там же, где оно все-таки практиковалось, не столько заботились об узниках войны «дружественных» национальностей, сколько руководствовались собственными прагматическими соображениями. Р. Нахтигаль, к примеру, считает, - и с ним, очевидно, следует согласиться, - что побарачное разделение пленников в соответствии с их этноязыковой принадлежностью позволяло поддерживать среди них «общую культуру» и тем самым облегчало управление этими людьми, - и не более того ${ }^{28}$.

\section{«Этнизация» плена между политической волей и экономической целесообразностью}

Впрочем, жирный крест на строгой изоляции «братьев-славян» от «проклятых» немцев, венгров, турок и евреев поставили не только и не столько на местах.

25. «О пленных славянах, мадьярах и немцах», Зауральский край, 1915, 28 окт.

26. ГАРФ, ф. 102, 2-е делопроизводство, оп. 73, д. 334, л. 29.

27. ГАСО, ф. 643 , оп. 1 , д. 3995 , л. 17 об.

28. Nachtigal, Russland und seine österreichisch-ungarischen Kriegsgefangenen, s. 26, 51. 
В то время как Генеральный штаб рассылал по внутренним округам России телеграммы о срочной отправке пленных «враждебных» национальностей в Сибирь, Министерство земледелия, столкнувшись с тем, что в конце 1915 г. из деревни оказались «изъяты» практически все вражеские военнослужащие, подготовило документ, требовавший остановить их переброску на Восток страны «ввиду ожидаемого в ближайшем времени интенсивного требования на рабочие руки» ${ }^{29}$. Больше того, по подписанному 25 января 1916 г. соглашению трех ведомств - военного, внутренних дел и земледелия - из-за Урала в Европейскую Россию было переведено порядка 100 тыс. немцев и мадьяр, что свело на нет практически все предпринятые ранее попытки «раскассирования» пленных сообразно с их этнической принадлежностью ${ }^{30}$. В феврале 1916 г. Генеральный штаб отдал прямое распоряжение о том, что, поскольку «все пленные подлежат незамедлительному командированию на работы, перегруппировку пленных по национальностям надлежит прекратить» ${ }^{31}$.

В битве за пленных, начавшейся между аграриями и промышленниками в середине 1916 г., сегрегации пленников по национальному признаку места и вовсе не находилось.

Ввиду необходимости оказать помощь как предприятиям, работающим на оборону, так и сельским хозяйствам для уборки урожая, военный министр приказал прекратить снятие военнопленных славян с каких-либо работ, а тех, которые уже были сняты, но еще не отправлены, спешно возвратить на те же работы, - сообщала пресса в начале августа 1916 г. ${ }^{32}$

В октябре того же года военное ведомство распорядилось незамедлительно вернуть на работы, «с коих были сняты», всех пленных, отказавшихся служить в национальных подразделениях или по каким-то причинам не принятым в эти подразделения ${ }^{33}$.

С изданием ретроспективных документов от трепетного отношения к пленным «дружественных» наций на периферии практически не осталось и следа. Оказавшиеся на работах пленники быстро поняли, что ни их перевод в более комфортные помещения, ни улучшение их питания и обмундирования, ни тем более предоставление им прав на работу по специальности, организацию касс взаимопомощи, проживание на частных квартирах, вступление в брак и т.д., и т.П. ни в чьи планы на самом деле не входили. Пользуясь тем, что всякая риторика о льготных условиях содержания пленных тех или иных национальностей вплоть до середины 1917 г. так и оставалась не более чем

29. ГАПК, ф. 146 , оп. 1 , д. 94 , л. $68,80,80$ об.

30. Там же, Л. 195.

31. РГВИА, ф. 1720, оп. 2, д. 185, л. 23.

32. «Военнопленные славяне на работах», Пермские ведомости, 1916, 10 авг.

33. РГВИА, ф. 1720, оп. 1, д. 87, л. 73, 74, 76, 257, 442. 
риторикой, - более или менее определенно на этот счет власти, пожалуй, высказались только в циркуляре от 22 декабря 1915 г. $^{34}$, - прислушиваться к ней местные хозяйственники не спешили. Прибыв в 1916 г. в распоряжение администрации Полазненского завода князя С.С. Абамелек-Лазарева, 135 пленных славян с удивлением обнаружили, что единственной их привилегией являлись более длительные, нежели у других пленных, прогулки ${ }^{35}$. В то же время галичанин Исидор Кардаш, обращаясь в Галицко-Русское общество как в последнюю инстанцию, писал:

[...] Вот уже один год работаю на железной дороге в Лысьвенском заводе и что вижу? Приехали здесь, в завод, пленные мадьяры и русины, и какое их содержание? Превосходное помещение, горячая пища 3 раза в день, мясо ежедневно, белье чистое, посуды всякой и одежды в изобилии; кроме того плата от 5 рублей в месяц. Есть такие, которые получают и 150 рублей в месяц - это ведь не плен, а самая хорошая должность. Потом приехали германцы на постройку новостроящейся Западно-Уральской железной дороги и получали 1 р. 20 коп. ежедневной платы. А славяне? Вот здесь одна партия работает на ветви Лысьва-Калино. Работа самая тяжелая - смена рельс и шпал, помещение грязное и скверное, а плата от 65 коп. до 80 коп. в сутки. За эти деньги они должны содержать себя, одежду и прочее... Посмотрите на их белье - у кого одна и последняя порванная рубаха, у которого на брюках 50 заплаток. Возле нас проходят мадьяры на работу и приносят продавать рубашки, которые им не нужны. И так живем один год. Контора обещала сначала такую же плату, как и русским рабочим, только половину мы не получаем так как она идет на одежду. Сейчас русские получают 2 р. 70 коп., а мы от 65 до 85 коп., и еще ни куска не видели с обещанной одежды. Шубы и валенки, которые зимой получили и которые мы из экстренной прибавки оплатили, забрали и увезли в Пермь. Я тоже вместе работаю. Лопата уже приросла к моим рукам... Я все Вам это пишу потому, что мне это ужасно больно и нравственно угнетает, иногда до сумасшествия... Почему же это так? Нужна ли моя мука комунибудь? Верно то, что, если б моя каторга нужна была для уничтожения германизма, я бы её с песнею на устах переносил. ${ }^{36}$

В не менее скверном положении очутились в конечном итоге и пленники прочих «дружественных» народностей. Так, в конце 1916 г., когда российское правительство, ссылаясь на дефицит рабочих рук, отказалось от ранее запланированной передачи «дружественных» итальянцев, французов и датчан союзным войскам Антанты, им тут же была оказана весьма сомнительная милость, состоявшая в более широком отпуске военнопленных названных национальностей, и в особенности специалистов, заводам и фабрикам,

34. ГАРФ, ф. 102, 2-е делопроизводство, оп. 73, д. 334, л. 19.

35. ГАПК, ф. 146, оп. 1, д. 95, л. 168, 168 об., 314, 328, 332.

36. Российский государственный исторический архив (РГИА), ф. 465, оп. 1, д. 32, л. 163-164. 
«изготовляющим предметы для нужд армии» ${ }^{37}$. В результате многие датчане, итальянцы и французы, на общих основаниях с другими пленниками заготовляя дрова или добывая руду где-нибудь в далекой провинции, никаких преференций со стороны властей так и не дождались. Осенью 1916 г. 40 эльзасцев, отправленных на работы в Верхне-Тагильское лесничество Верх-Исетских горных заводов, подали жалобу на имя французского военного агента в Петрограде, претендуя на особое к себе отношение, многократно обещанное российскими властями, но так ими и не оказанное. Один из «жалобщиков», уроженец Страсбурга Марсель Шварц при этом отмечал:

Хотя я и германский подданный, но чувствую себя французом и буду ходатайствовать об отправке меня во Францию, на позиции. Я и многие мои товарищи заявили об этом еще в Киеве, где нам сказали, что нас отправят во Францию, когда путь туда будет свободен. Затем нам сказали, что мы будем работать в заводе, изготовляющем военные припасы, что для нас было бы более подходяще, а на лесных работах мы оказались совершенно неожиданно для себя, и все это, вместе взятое, нервирует нас. ${ }^{38}$

Данное главным лесничим Верх-Исетского округа Г.Ф. Федзюшко объяснение по делу свидетельствовало, что положение пленных французов на самом деле ничем не отличалось от положения других пленных, и считаться с их «дружественной» национальностью никто не собирался:

Порядок продовольствования и режим для пленных эльзасцев тот же, что существовал и ранее для других пленных. И порядок этот, надо полагать, вполне удовлетворителен, так как ни нашей администрации, ни объезжавшему горные округа в феврале и марте 1916 г. с целью обследования положения военнопленных вице-губернатору г-ну Максимову жалоб не поступало... Порядок продовольствования и режим ни в коем случае не мог быть изменен, так как прежде всего запротестовали бы пленные, прибывшие на работы ранее эльзасцев, и старые пленные обратили бы на это обстоятельство внимание вновь прибывших. Вновь прибывшие эльзасцы нами не изолированы, а размещены группами среди ранее прибывших [пленных]... Вообще порядок расценки [за труд], режим и продовольствие установились практикой и поддерживаются как наиболее целесообразные и не вызывающие протеста. Кроме того, военное ведомство было осведомлено о том, что нам требуются военнопленные на рубку дров и, откомандировывая эту партию эльзасцев, по-видимому, или не имело более легких работ, или желание эльзасцев получить легкую работу в лучших климатических условиях не признало заслуживающим уважения. ${ }^{39}$

37. ГАПК, ф. 146, оп. 1, д. 95, л. 112; ГАСО, ф. 72, оп. 1, д. 5641, л. 73.

38. ГАСО, ф. 55, оп. 2, д. 1128 , л. 13 об.

39. Там же, л. 15-16. 
Требования пленных эльзасцев отправить их во Францию, дабы они могли как можно скорее пополнить ряды ее защитников, чиновники военного ведомства также оставили без удовлетворения, прикрывшись мнением французской комиссии, посетившей Урал в декабре 1916 г. Эта комиссия, сообщалось упомянутому выше М. Шварцу, рекомендовала-де эльзасцам «оставаться на работах в России, а не переводиться на позиции во Франции, дабы их семейства в Эльзасе не подверглись репрессиям со стороны германского правительства ${ }^{40}$. В то же время, не добившись от администрации ВерхИстеских горных заводов никаких послаблений в отношении пленных французов, Казанский военный округ все-таки решил снять последних с работ предприятия. Но, что называется, не тут-то было. В январе 1917 г. администрация Верх-Исетских горных и механических заводов, минуя Казань, апеллировала к Генеральному штабу:

[B] октябре нам назначено для работ, связанных с исполнением заказов [на] оборону, триста одиннадцать пленных эльзасцев и лотарингцев. [В] настоящее время [по] распоряжению Казанского военного округа полиция требует передачи их воинскому начальнику. Снятие столь значительного количества рабочих, когда в них ощущается острый недостаток, неминуемо отразится на работах на оборону. Ходатайствуем [об] оставлении их впредь до замены пленными других национальностей ${ }^{41}$.

Ходатайство управления округом поддержал уполномоченный по топливу Уральского района, убедивший военные власти в необходимости «в виду серьезности настоящего вопроса» погодить со снятием пленников с работ ${ }^{42}$.

Очевидно, таким образом, что на местах, где пленные французского происхождения, равно как и любого другого, рассматривались прежде всего как дешевая рабочая сила, политико-идеологические императивы имели весьма ограниченную власть. До пленников не доходили не только положенные им льготы и послабления, но и такая малость, как газеты, издававшиеся на различных национальных языках и преследовавшие, казалось бы, исключительно благие цели.

Один из подведомственных мне чинов доложил, что на имя некоторых из состоящих в его ведении военнопленных стали поступать номера издающейся в Петрограде газеты «Чехословак». Находя, что чтение военнопленными из нижних чинов газет, хотя бы и не вредных русской государственности, может вредно отразиться на успешности производимых ими работ, и, считая это вообще совершенно излишней роскошью, предлагаю никаких газет военнопленным не передавать, а все получаемые на их имя номера газет посылать в управление, -

40. Там же, л. 20, 23, 23 об.

41. ГАСО, ф. 111, оп. 1, д. 20, л. 65 об. См. также: РГВИА, ф. 1720, оп. 1, д. 87, л. 449.

42. ГАСО, ф. 72, оп. 1, д. 20, л. 5641, л. 66. 
постановил начальник Пермского управления земледелия и государственных имуществ А.А. Дубенский ${ }^{43}$, откровенно противореча тем самым инструкциям военного ведомства, приветствовавшего распространение среди пленников изданий, «придерживающихся явно выраженного антигерманского направления» («Gazeta Polska», «Echo Polskie», «Словенские гласы», «Чехословакия», «Славянский вестник» и других $)^{44}$.

Источники свидетельствуют, что серьезные надежды на превращение иллюзии «всеславянского единения» в реальность связывались пленниками с Февральской революцией, которую многие из них поспешили поддержать. 25 марта 1917 г. в газете «Уральская жизнь», к примеру, появилось письмо 125 пленных чехов, преисполненное панславянского пафоса и соответствующего «жаргона»:

Группа военнопленных чехов в Нижнем Тагиле радостно и восторженно приветствует победу великого и светлого дела - освобождение русского народа от ига, которое до сих пор угнетало его. Мы, сыновья демократического народа, который существование свое и свободу защищал целыми веками от того врага, который был и Вашим врагом, с восторгом поздравляем Вас с великой победой братского славянского русского народа... Русский народ в этой роковой борьбе поднял знамя революции во имя свободы, во имя культуры человечества; доблестная армия его сражается против исконного врага всего славянства: против германизации, против германского милитаризма. Мы, которые освободились от позорящего нас австрийского ига, тоже подняли красное знамя революции против наших притеснителей. Тысячи наших борцов-революционеров сражаются теперь бок о бок с русскими солдатами-революционерами против общего нашего врага, поражение которого значит освобождение малых славянских народов, которые до сих пор страдают под деспотическим игом коварного врага. Да здравствует Свободная Россия! Да здравствует Свободная Славия! ${ }^{45}$

В Оренбургской и Уфимской губерниях пленные чехи и словаки выступили даже с инициативой организовать специальные комитеты с целью «открытого революционного движения» против австро-венгерского правительства, что, однако, поставило власти в тупик.

[...] В настоящее время, пока не будет устойчивого положения на фронте, дать такое разрешение не представляется возможным, так как теперь всякое движение при агитации темный сил может быть использовано во вред нам, -

43. Г.г. лесничим Пермской губернии, в ведении которых состоят военнопленные: Циркуляр № 329 от 7 декабря 1915 г. // Циркуляры начальника Пермского управления земледелия и государственных имуществ о порядке использования труда военнопленных за 1915 год (с приложениями), Пермь, 1916, с. 26.

44. ГАПК, ф. 146, оп. 1, д. 94, л. 191, 252, 389, 554.

45. «Приветствие военнопленных чехов», Уральская жизнь, 1917, 25 марта. 
- уклончиво ответствовало на просьбу пленников Главное управление Генерального штаба, обнаруживая ограниченность оказываемого им доверия и невысокую востребованность их «свободоборческих» потенций ${ }^{46}$.

Совершенно неожиданно для властей помимо горячего отклика со стороны «братьев-славян», видевшегося вполне закономерным результатом соответствующей пропаганды, свержение самодержавия всколыхнуло и «враждебных» в этническом отношении военнопленных, связывавших изменение политического строя в России с возможным изменением дискриминационной политики национальностей и политики плена вообще. Мадьяр Г. Гутман писал в апреле 1917 г. в Петроград председателю Совета рабочих и солдатских депутатов Н.С. Чхеидзе:

[...] Пока придет окончательное освобождение, я прошу вас, я умоляю вас, дорогой брат, властитель сердец, заступитесь за наших и ваших братьев венгерцев... Не допустите, чтобы в этой великой святой борьбе, которая очистила русский воздух, не допустите наших братьев, несчастных из несчастнейших военнопленных, оставить неосвобожденными. Не допустите, чтобы в этот великий день, который великому русскому народу принес освобождение, стал днем проклятия для военнопленных. Уделите в вашем великом сердце небольшое местечко и для нас, несчастных. ${ }^{47}$

Попытки военнопленных применить «по отношению к себе объявленную свободу граждан Российского Государства» 19 апреля 1917 г. прокомментировал военный министр Временного правительства А.И. Гучков, охарактеризовав все претензии вражеских военнослужащих на либерализацию плена как противоречащие «самому понятию состояния плена, неразрывно связанному с ограничением свободы» ${ }^{48}$. Вместе с тем, по мнению экспертов, свержение самодержавия все-таки внесло некоторые коррективы в политику российского плена. Двойственность, характерная для позиции царского режима, была заменена явной поддержкой со стороны Временного правительства России, указывает А. Рачамимов, имея в виду отношение властей к проблеме возможной реинтеграции военнопленных в продолжавшийся международный вооруженный конфликт ${ }^{49}$. Действительно, 24 марта 1917 г. Военным советом было подписано «Положение о формировании чешско-словацких войсковых частей», подразумевавшее пролонгацию курса на этнизацию плена и национализацию армии. В июне 1917 г. параллельно с интенсифицировавшимся набором добровольцев в национальные формирования ${ }^{50}$ началась еще и очередная кампания

46. ГАРФ, ф. 1791 , оп. 2, д. 557, л. 1-4.

47. Там же. ф. р-6978, оп. 1 , д. 816 , л. 1 .

48. ГАСО, ф. 72 , оп. 1 , д. 5641 , л. $65,68$.

49. Rachamimov, POWs and the Great War, p. 118.

50. См. об этом, к примеру: Телеграмма Пермскому губернскому комиссару из Казани, 12 августа 1917 г. // Пермский вестник Временного правительства, 1917, 23 авг; Телеграмма Пермскому губернскому комиссару из Казани, 25 августа 1917 г. // Там же, 27 авг;; и др. 
по перегруппировке пленных по национальному признаку ${ }^{51}$. В июне же 1917 г. был, наконец-то, подписан документ, оговаривавший льготные условия содержания пленных чехов, словаком и поляков, распространенные впоследствии на «югославян», румын, итальянцев и французов ${ }^{52}$.

Однако, одной рукой раздавая пленным «дружественных» наций знаки своей благосклонности, другой рукой власти их тут же отбирали. В мае 1917 г. Особая междуведомственная комиссия настолько ужесточила порядок принятия военнопленными славянами российского гражданства, что впору было говорить о серьезных барьерах, мешавших им обрести новую родину ${ }^{53}$. Вновь дарованные вражеским военнослужащим «дружественных» народностей льготы - при том что они и ранее по большей части только имитировались - очень скоро также обнаружили свою ограниченность. Круг их потенциальных получателей со временем серьезно сузился, объединив только тех военнопленных, которые дали согласие на вступление в национальные добровольческие формирования ${ }^{54}$.

Между тем, курсу на «этнизацию» плена продолжали сопротивляться и местные экономические элиты. Расследованием по делу пленного Фиалы Франтишека, многократно просившего Гимнастическое общество «Сокол» в Киеве, редакцию журнала «Чехословак» и Союз чехословацких обществ в России поспособствовать его отправке в Чешскую дружину, было, к примеру, установлено, что пленные чехи намеренно не отпускались с работ, так как «управление Богословским округом, считая их хорошими рабочими, умышленно ставило им в этом всякие препятствия» ${ }^{55}$. Давление со стороны промышленников заставило власти уступить, серьезно изменив уже указанное «Положение о формировании чешско-словацких войсковых частей». Летом 1917 г. было, в частности, решено, что

набор военнопленных чехов и словаков для формируемых войск должен производиться исключительно из числа чернорабочих, сохраняя всех военнопленных, обладающих какой-либо специальною техническою подготовкою, для нужд промышленности и не допуская ухода их с работ. ${ }^{56}$

Кроме того, соединение братских народов «в одних взглядах, в обоюдных воспоминаниях как об общих боях, так и об общих страданиях и победах» ${ }^{57}$

51. ГАПК, ф. 146, оп. 1, д. 21а, л. 67; РГВИА, ф. 1720, оп. 1, д. 108, л. 576, 782.

52. ГАСО, ф. 45, оп. 1, д. 232, л. 30-31; ф. 72, оп. 1, д. 5641, л. 58-58 об.

53. «Объявление Пермского губернского комиссара», Пермский вестник Временного правительства, 1917, 28 сент.

54. «Объявление Пермского губернского комиссара», Там же, 14 окт.

55. ГАСО, ф. 24 , оп. 20 , д. 2825 , л. 71-71 об.

56. «Объявление Пермского губернского комиссара», Пермский вестник Временного правительства, 1917, 27 июля.

57. «К вопросу о помощи военнопленным славянам», Там же, 13 мая. 
осложнялось появлением после свержения царского режима целого ряда новых структур, влиявших наряду с хозяйственниками на ситуацию на местах. Специальные уполномоченные правительства Румынии, командированные в провинцию для набора добровольцев из числа военнопленных, обнаружили, к примеру, что

всевозможные комитеты и комиссии из рабочих при фабрично-заводских предприятиях и железнодорожных станциях ... умышленно препятствуют набору и отправлению выбранных пленных румын. ${ }^{58}$

Очевидно, таким образом, что политика национальностей в пространстве российского плена никогда не была столь твердой, как это пытаются показать многие исследователи. Репутационные издержки, связанные с реанимацией и культивацией образа России как защитницы всего славянства, требовали от руководства страны не только соответствующих деклараций, но и адекватных декораций, (вос)производство которых оказалось задачей не из легких. Кроме того, в условиях вызванного войной роста национального самосознания панславистская идея уже не обладала той степенью привлекательности, которая бы позволяла жонглировать национальными чувствами пленников без всяких последствий. Попытки прагматизации этничности актуализировали тот факт, что «славянский мир» единства на самом деле не составлял, а если и составлял, то только в смысле единства множественностей и разнообразий. Власти Саратова, к примеру, столкнулись с тем, что пленные поляки отнюдь не считали своими братьями пленных чехов. Наоборот, они, вступавшие в национальную дружину, рассматривались не иначе как предатели. Военнопленных поляков майора Лубиенского и поручика Сулемирского решено было даже срочным порядком этапировать в Кунгур и Екатеринбург соответственно, поскольку они, активно выражая свое неудовольствие «родственниками», не без успеха провоцировали разлад и смуту в рядах солагерников ${ }^{59}$.

\section{Манипулируя верой: политика благоприятствования пленным православного вероисповедания}

«Завоевания» гражданских властей в деле реализации идеи «divide et impera» были бы, возможно, еще скромнее, не подключись к ее воплощению Русская православная церковь. Не секрет, что фактор религиозной принадлежности в течение веков служил одним из главных ориентиров при юридическом оформлении отношения к плененным в ходе того или иного вооруженного

58. «Объявление от Пермского губернского комиссара», Там же, 10 окт.

59. РГВИА, ф. 1720 , оп. 1 , д. 87 , л. 637. 
конфликта иностранцам ${ }^{60}$. В условиях формирования современных национальных государств такого рода практика, свойственная традиционным обществам, постепенно отмирала, так как старые идентификационные коды, постепенно утрачивая свою актуальность, уступали свое место новым. В России же начала ХХ в., где процесс таковой «перекодировки» только обозначился, и религия продолжала оставаться «понятным языком идентичности», вера по инерции продолжала рассматриваться в качестве важного индикатора лояльности пленников, а утилитаризация их религиозных предпочтений превращалась в одну из приоритетных задач. Следует, правда, отметить, что на предмет религиозных нужд вражеских военнослужащих российские власти, в отличие, скажем от властей германских ${ }^{61}$, так и не «обзавелись» четкой позицией. Больше того, то препятствуя, то благоприятствуя празднованию пленниками католического Рождества или иудейских Йом-Кипура и Суккота, допуская или не допуская капелланов к участию в службах, разрешая или не разрешая погребение умерших в соответствии с теми или иными обрядами, представители военной и гражданской администрации России обнаруживали тот факт, что обеспечение обезоруженных вражеских военнослужащих привычной для них духовной пищей нормой не являлось ${ }^{62}$. Еще более последовательны и однозначны при этом были работодатели, вопреки всяким преподанным свыше регламентам не отпускавшие пленных в костел и даже штрафовавшие их «за отлучки для присутствования на богослужениях» ${ }^{63}$.

Вместе с тем, для военнопленных православного вероисповедания, среди которых большинство составляли этнические славяне, в вопросах веры и культа последовательно создавался режим наибольшего благоприятствования. 16 мая 1915 г. по указу Его Императорского Величества Святейший Правительствующий Синод заслушал рапорт епископа Екатеринбургского и Ирбитского Серафима и принял решение о допущении к Св. Тайне военнопленных австрийцев, «заявляющих о принадлежности к православному исповеданию, но не могущих представить документальных данных в подтверждение этого заявления» ${ }^{64}$.

Летом 1915 г. Синод отдал распоряжение епархиальным властям об устройстве с военнопленными славянами религиозно-нравственных бесед,

60. См. подробнее: Н.В. Суржикова, «Эксплуатация веры: конфессиональный фактор в российском праве военнопленных конца XVII - начала XX века», Война и сакральность: Материаль Четвертых Междунар. науч. чт. «Мир и война: культурные контекстьл социальной агрессии», М. - СПб., 2010, с. 152-155.

61. См. об этом: О.С. Нагорная, «Религиозная жизнь российских военнопленных в немецких лагерях в годы Первой мировой войны», Отечественная история, 2008, № 5 , с. $225-226$.

62. ГАПК, ф. 146, оп. 1, д. 94, л. $132,500,507$; ф. 280, оп. 1, д. 2752, л. 410; РГВИА, ф. 1720, оп. 2, д. 161, л. 635; и др.

63. ГАСО, ф. 643 , оп. 1 , д. 3995 , л. 17 об.

64. «Отдел официальный», Екатеринбургские епархиальные ведомости, 1915, № 26, c. 351-352. 
первые из которых состоялись на местах еще до выхода названного документа. В Екатеринбурге, к примеру, они были организованы по инициативе епархиального миссионера протоирея Александра Здравомыслова. Дважды посетив кирпичеделательный завод П.Ф. Давыдова, отец Александр выяснил, что работавшие здесь пленные русины, будучи униатами, предпочитали посещать не костел, а православный храм, и «к слушанию бесед и поучений православного священника они весьма расположены» ${ }^{65}$. Развернуть бурную деятельность на этом поприще батюшке помешало было отсутствие соответствующего разрешения со стороны властей, но оно заставило себя ждать совсем недолго. Объезжавший весной 1915 г. свои «владения» Харьковский архиепископ Антоний заметил, что пленные галичане, молдаване, сербы, чехи и словаки православного и униатского исповедания весьма усердно посещают православную службу. «Между тем, исключая немногие епархии, эти достойные всякого участия наши единоверцы и одноплеменники остаются без всякой заботы со стороны церкви», - подытоживал приходящие с мест сигналы обер-прокурор Святейшего Синода ${ }^{66}$. В связи с этим

[...] в ведомстве православного вероисповедания возникла мысль основать во всех губерниях под председательством преосвященных, с участием и представителей местной государственной власти, попечительные о пленных православного и греко-униатского исповедания братства, которые должны быть снабжены определенною инструкцией строго церковного и патриотического направления. ${ }^{67}$

С таким заманчивым предложением военное ведомство не согласиться просто не могло, рассматривая специальные епархиальные попечительные комитеты в качестве инструмента приобщения пленных славян не только к «истинным ценностям», а если потребуется - то и к священной войне «против врагов всего славянства» ${ }^{68}$. Как результат сокровенные беседы с пленниками быстро превратились в назидательные лекции, а редкие визиты служителей культа к местам их работ - в организованные экспедиции. В одной из них отметился вице-председатель Всероссийского русско-черногорского благотворительного общества, священно-синеккел Черногорской митрополии иеромонах Мардарий (в миру Иван Ускокович), в то время обучавшийся в Петроградской духовной академии, а впоследствии возглавивший Американо-Канадскую епархию Сербской православной церкви. Командированный в августе 1915 г. на Урал, он посетил предприятия Нижне-Тагильского, Луньевского и Богословского горных округов. В беседах с военнопленными отец Мардарий,

65. ГАПК, ф. 65 , оп. 3, д. 593, л. 262, 262 об.

66. РГВИА, ф. 1720, оп. 2, д. 161, л. 419, 422, 697.

67. ГАПК, ф. 65, оп. 3, д. 593, л. 265, 265 об.

68. «Распоряжение Святого Синода», Уральская жизнь, 1915, 13 окт. 
указав на тяжелое положение славян, подпавших под иго Австрии и Германии, $[\ldots]$ одобрил их поступок отдаться в плен и $[\ldots]$ не проливать кровь своих родных братьев славян. ${ }^{69}$

В Морозковском лесничестве в одной казарме, населенной исключительно сербами, военнопленные встретили Мардария радостно и заявили ему, что они были бы очень рады, если бы Русское правительство допустило бы их в ряды своей армии и позволило бы сражаться против Австрии - векового их угнетателя $[\ldots],-$

рапортовал полицейский исправник Верхотурского уезда пермскому губернатору по итогам поездки православного миссионера, подчеркивая их исключительно позитивный характер ${ }^{70}$.

Главным же итогом деятельности Екатеринбургского епархиального попечительного комитета о пленных стало, очевидно, православное крещение 23 июня 1916 г., в день памяти Яна Гуса, 26 военнопленных чехов (21 офицера и 5 денщиков из нижних чинов) $)^{71}$. После него в Златоустовском храме Екатеринбурга даже образовался чешский хор, который просуществовал до 24 июля 1916 г., когда новокрещеные «как верные воины Христовы и как истинные славяне, подкрепленные желанием освободить бедное свое Отечество», в полном составе отбыли в расположение чешских частей русской императорской армии ${ }^{72}$. Примеру соотечественников в августе 1916 г. последовало еще несколько «добрых» чехов, в скором времени также отправившихся в войска ${ }^{73}$. В то же время в Омске уже насчитывалось порядка 300 военнопленных славян, перешедших в православие, включая 140 русинов, 129 чехов, 14 поляков, 5 словаков и одного хорвата ${ }^{74}$.

Очевидно, что «эксплуатация» веры, нацеленная на интеграцию пленников не столько в духовную, сколько в политическую жизнь, со всей откровенностью обнаруживала свою сервильность. Однако такое положение вещей складывалось главным образом там, где пленные были досягаемы для систематической «обработки», в то время как религиозная жизнь всех прочих обнаруживала другую крайность. Она, даже несмотря на визиты проповедников, как правило, ограничивалась личными отношениями военнопленных с Богом, защищенными от массированного вторжения извне лесами, горами, полями и

69. ГАСО, ф. 183 , оп. 1 , д. 72 , л. $37-38$.

70. Там же.

71. «Ходатайство пленных чехов», Зауральский край, 1916, 10 июня. По данным, приводимым в «Екатеринбургских епархиальных ведомостях», новоприсоединенных было 25, а не 26 человек (См.: «Отдел неофициальный», Екатеринбургские епархиальные ведомости, 1916, № 26, с. 209-212).

72. «Чешский хор», Зауральский край, 1916, 3 июля; «Добровольцы-чехи», Там же, 29 июля; «Прощальный привет», Там же, 2 авг.

73. [Без названия], Уральская жизнь, 1916, 21 авг.

74. «Переход в православие военнопленных», Правительственный вестник, 1916, 17 июня. 
т.д., что более чем наглядно зафиксировала одна из жалоб пленников середины 1916 г.: «Живём здесь, как дикари в пустыне: ни церкви, ни костела, за все время один раз видели ксендза» ${ }^{75}$.

Образовавшийся таким образом зримый разрыв между двумя полюсами, на одном из которых религиозная жизнь была выставлена на показ, а на другом оставалась невидимой и неведомой, показывал, что поверхностный интерес к внутренним переживаниям пленников заботы об их психологическом здоровье как таковой вовсе не касался. Он, скорее, стал дополнительным средством апелляции к образу праведной и жертвенной Святой Руси, - образу, взывавшему прежде всего к сознательному и бессознательному «аборигенного» населения. И что при этом было важнее, еще одна возможность нажима на общество посредством ретрансляции основ его «Я-концепции» или их инструментализация в целях прагматизации плена, остается вопросом.

$$
* * *
$$

Нет сомнений, что ни «этнизация», ни сопровождавшая ее «конфессионализация» российского плена 1914-1917 гг. в конечном итоге так и не стали необратимыми процессами. Основанные на различиях и неравенствах, они часто оборачивались атомизацией пленников, а не консолидацией той их части, которая рассматривалась властями как полезный политический ресурс. В этой связи речь в данном случае изначально шла не только и не столько об эффективной политике, сколько о формировании определенного властного дискурса, посредством которого воюющее общество должно было ориентироваться в своих актуальных действиях и противодействиях. Проблема, однако, состояла в том, что рисунок этих действий и противодействий на местах формировался еще и сообразно с самыми разными интересами, мотивами и целями, конвенциональность которых являлась для «населявших» территорию плена индивидов и групп недостижимой мечтой, что окончательно лишало политико-идеологический курс, проводимый в отношении узников войны, устойчивости. Вместе с тем, всяческие политические «танцы» вокруг пленных иностранцев позволяли не без успеха поддерживать иллюзию их массового политического активизма, дезавуируя тот факт, что из 2-миллионой армии неприятельских военнослужащих таковой проявили только несколько десятков тысяч человек. А потому политико-идеологические манипуляции в пространстве российского плена 1914-1917 гг., будучи его самой известной главой, могут считаться его самой значимой главой лишь с некоторыми оговорками.

Ural'skij federal'nij universitet

snvplus@mail.ru

75. Государственный архив в г. Тобольске, ф. и-152, оп. 27, д. 191, л. 209. См. также: Там же, л. 211 и др. 